\title{
Content-based Instruction in the Teaching of English for Accounting at Vietnamese College of Finance and Customs
}

\author{
Nguyen Thi Chau Ngan \\ College of Finance and Customs \\ B2/1A, 385 Street, Tang Nhon Phu A Ward, District 9, Ho Chi Minh City, Vietnam \\ E-mail: ntchaungan5979@yahoo.com
}

Received: January 25, 2011 Accepted: February 10, 2011 doi:10.5539/elt.v4n3p90

\begin{abstract}
The overwhelming weight of emphasis in language analysis in the teaching of English for Accounting (ESP) has been a concern for teachers of English at the College of Finance and Customs (CFC). In the ESP course, the teaching materials teach students to recognize the surface form by means of the specialist texts. The difficulties the students and teachers encounter are the unfamiliarity with the specialist contents and far too complex sentence structures. Faced with this reality, the researcher produced a syllabus which gave high priority to the language form and content via simplified language and authentic materials. To do this, firstly the researcher incorporated the Content-Based Instruction (CBI) approach in the ESP context, and then the ESP material designed in the CBI approach was used in the treatment group in one semester. To see its effects when the course finished, the researcher administered a survey including the post test and the questionnaire. The findings from this research reveal the students' interest, and involvement in the course. Also, they highlight the students' ability to get better scores in all modes of ESP.
\end{abstract}

Keywords: ESP, CBI, Quasi-experimental, Treatment group (TG), Control group (CG)

\section{Introduction}

The unprecedented spread of English throughout the world in recent years has resulted in its major role and high prestige in the academic, cultural, and political landscape of a growing number of countries (Crystal, 1995, 1997; Fishman, Cooper, and Conrad, 1977; McArthur, 1998, 2002, para. 1). Because of its international role in economic relations, and cultural exchange with foreign countries, the need for communication in English is becoming more and more important. As Harmer (1991) indicates "people want to study English because it offers a chance for advancement in their professional lives".

"Traditionally the aim of linguistics had been to describe the rules of English usage, that is, the grammar. However the new studies shifted attention away from defining the formal features of language usage to discovering the ways in which language is actually used in real communication" (Widdowson, 1978, in Hutchinson \& Waters, 1987, p. 7). With subsequent developments, it required an emergence for English courses tailored to specific needs for groups of learners that people called ESP.

Since its beginning in the late 1960s, ESP has drawn upon three major realms of knowledge: language, pedagogy and the students/ participants' specialist areas (Hutchinson \& Waters, 1987, p. 9). ESP's emergence seems to meet the learners' need in the specialized realm. However, after some initial success, ESP was found to be of some limitations to both teachers and learners. Hutchinson and Waters (1987) indicate that as well as having to cope with the uncertain values of the strange land of ESP, ESP teachers may also have to struggle to master language and subject matter beyond the bounds of their previous experience.

ESP is language-centred, and the language-driven approach is in its dominance. This mode unintentionally poses many difficulties on teachers and learners as they have to cope with linguistics surface form through monotonous specialist texts. Rivers (1992) points out that although learners can participate in memorized conversations easily and effortlessly, hardly any can produce at length fluent variations from the basic materials, and none could talk on unrehearsed topics without hesitation.

In the trend of integration nowadays, a country can hardly be isolated and self-sufficient. So, Vietnam has become the $150^{\text {th }}$ member of the Word Trade Organization. More and more foreign investors have poured capital into Vietnam. At this time, English is the ultimate means of communication in foreign trade. To meet the society's needs, 
Vietnamese students must have sound English knowledge to work well in their jobs. They are not only qualified at general English (GE) but also capable of interpreting the specialist contents. With such great concerns, choosing an appropriate learning material in harmony with suitable teaching methods is considered as a vital and primary concern for ESP teachers, language program developers, and also curriculum designers.

To the current ESP material, its contents are written for learners who study accounting profession and English is their mother tongue. Therefore, this material is considerably inappropriate to the students' English level of both content and language structure. To some aspects, this present syllabus neglects the purpose of combining language and content together. As a result, students are mainly exposed to linguistic features and passively stuffed with new words in the field.

So, the selection of authentic contents in simplified language suitable to the students' English level will be the priority when designing an ESP syllabus.

The research is carried out to answer the guiding question and two sub-questions that follow:

Is teaching English for Accounting by the CBI approach more effective than by the traditional methods?

The sub-questions are:

1) Are students in the TG more interested, motivated and involved in class activities during the course?

2) Do students in the TG learning with the material designed in the CBI approach achieve better scores than students in the CG learning with the current ESP material?

\section{Review on journal writing}

\subsection{History of ESP}

Hutchinson and Waters (1987) point out that ESP is an approach to language teaching in which all decisions as to content and method are based on the learners' reason for learning. This means that much of the work done by ESP teachers is concerned with designing appropriate courses for groups of learners.

Following this view, much of emphasis in ESP research and materials has been on the language analysis. ESP learners just learn English in order to be able to read the specialist texts, and other language skills seem to hold the secondary roles in learning. This might conclude that ESP lessons would concern themselves only with the activity of reading texts. So, first and foremost, "language-centred course design is the most familiar and prevalent in ESP" (Hutchinson \& Water, 1987, p. 65).

In the words of Dudley-Evans and St John (1998), in ESP approach, language-centred course design is the simplest kind of course design process and is probably the one most familiar to English teachers. This course proceeds as follows:

Identify learners' target situation

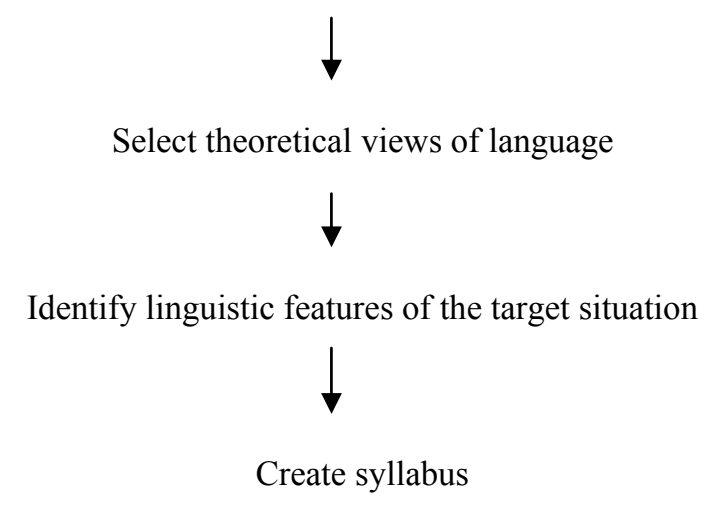

To this process, "the language-centred analysis of target situation data is only at the surface level. It reveals very little about the competence that underlines the performance" (Hutchinson \& Waters, 1987, p. 68). Moreover, ESP content is either at monotonous level with much repetition on isolated words of the specialist or academic which is too beyond the learners' competence.

Meanwhile, learners' primary aim of learning a foreign language is to be able to use it in real communication. This requires the authentic input so that learners have a feeling of absorbing something real and interesting. Hutchinson 
and Waters (1987) indicate that a text can only be truly authentic, in other words, in the context for which it was originally written, or "content can provide a motivational and cognitive basis for language learning since it is interesting and of some value to the learners" (Brewster, 1999, p. 84).

Generally speaking, a sound learning material going in harmony with appealing teaching methods will naturally kindle the students' interests and motivation. Gardner and Lambert (1972) point out that motivation is very strongly related to achievement in language learning.

\subsection{The CBI approach}

Brinton, Snow and Wesche (1989) indicate that in adult basic education, including the learning of English for speakers of other languages, content-based instruction is the instruction that focuses upon the substance or meaning of the content that is being taught. This is in contrast to "general literacy" or "general language" instruction, which uses topics or subject matter simply as a vehicle for teaching reading and writing, or the grammar or other "mechanics" of English language. Also, there are some following definitions that are typical for the CBI research:

Crandall and Tucker (1990, p. 187) define it as "an approach to language instruction that integrates the presentation of topics or tasks from subjects matter classes within the context of teaching a second or foreign language".

Or in the words of Wesche (1993, p. 42), CBI is aimed at the development of use-oriented second and foreign language skills and is distinguished by the concurrent learning of a specific content and related language use skills.

CBI approaches "view the target language largely as the vehicle through which subject matter content is learned rather than the immediate object of the study" (Brinton et al., 1989, p. 5).

Richards and Rodgers (2001, p. 204) point out “ CBI is an approach to second language teaching in which teaching is organized around the content or information that students will acquire, rather than around a linguistic or other type of syllabus".

All the above-mentioned definitions share similar characteristics relating to language and content. First and foremost, CBI satisfies learners with the following factors:

- Authentic materials: "there are two implications of authenticity - one implication is that the materials are similar to those used in native language instruction; the other relates to the use of newspaper and magazine articles and any other media materials that were not originally produced for language teaching purposes" (Brinton et al., 1989)

- Students' motivation increasing: "CBI provides the opportunities for teachers to match students' interest and needs with interesting, comprehensible, and meaningful content" (Brinton et al., 1989). Also, Littlewood (1981) indicates that CBI classroom is learner-centred rather than teacher-centred. In such classroom, students learn through doing and are actively engaged in the learning process, they do not depend on the teacher to direct all learning or to be the source of all information.

- Active teachers' pedagogy: Stryker and Leaver (1993) point out that CBI requires better language teachers to select and adapt authentic materials for use in class and create learner-centred classrooms. Or "an attempt is often made to integrate the topic into the teaching of all skills" (Brinton et al., 1989). In addition to this, teachers make all possible efforts to keep language learning and content exploration objectives in balance.

- Evaluation: Brinton et al. (1989) state that the goal of CBI is to assist learners in developing general academic language skills through interesting and relevant contents, so students are evaluated all skills of language. Since language cannot be used in a vacuum, it must be used to communicate about something. Therefore, it is likely that language assessment will need to be based on the topics and tasks used in instruction.

\subsection{Theme-based model in designing ESP material}

Brinton et al. (1989) indicate that theme-based courses constitute the most common model in CBI thanks to its relative lack of complexity for implementation. In theme-based model, selected topics or themes provide the content for students to learn. Themes are the central ideas that organize major curricular units, thus they have to be chosen to be appropriate to students' academic and cognitive interests and needs. Moreover, materials in theme-based language instruction are usually teacher-generated or adapted from outside sources.

For Eskey (1997), theme-based instruction adds a missing dimension to traditional approaches to language syllabus design. Where both form-based and notional/ functional syllabi focus on rules, rather than on real communication, theme-based language courses give learners an interesting subject to learn or communicate about. Language is used to explore content, and language growth emerges as students need to comprehend or produce language relating to content. 
Theme-based CBI is particularly appealing in this respect because teachers can use almost any content materials that they feel their students will enjoy. Brinton et al., (1989) indicate that authentic materials with simplified language are of great choice with an attempt to integrate the topic into the teaching of all language skills. Moreover, Grabe and Stoller (1997) share that keeping students motivated and interested are two important factors underlying content-based instruction. Motivation and interest are crucial in supporting student success with challenging, informative activities that support success and which help the students learn complex skills.

\section{Research methodology}

\subsection{Participants}

100 students from two classes, $\mathrm{C} 6 \mathrm{~B} 1 \mathrm{~b}$ and $\mathrm{C} 6 \mathrm{~B} 1 \mathrm{~d}$, were chosen to be the target in the research. All these students were in the same year of learning and major, and had equivalent English level via their placement test at the beginning of the new school year. Their age all varied from 18 to 20 and their predominant gender was female.

To do this study, randomly the researcher chose class C6B1b to be the TG who learnt ESP with the CBI approach. At the same time, class C6B1d was the CG who was taught with the current ESP syllabus by the same ESP teacher. In order to reduce bias to its minimum, the ESP teacher for these two groups was another appointed by the head of Foreign Language Faculty (FLF) at CFC.

\subsection{Instruments}

Instruments for carrying out the research were the material input for CBI application in the TG in the quasi-experimental stage, the post-test, and the questionnaire.

\subsubsection{The quasi-experimental design}

In the words of Kumar (1996), studies can be classified as: experimental, non-experimental and quasi-experimental. For the first one, it involves the researcher introducing the intervention that is assumed to be the "cause" of change, and waiting until it has produced the change. The second consists of the researcher observing the phenomenon and attempting to establish what caused it. To the last one, it has the properties of both experimental and non-experimental studies.

Based on the above theory, the quasi-experimental design shares some characteristics of true experiments which seeks interventions or treatments. Due to some limits in the setting of the study - a short time for the research, one semester, and the unsatisfactory results of the ESP courses over the last few years, the researcher applied the quasi-experimental design to the study. Following this design, which required the intervention in the ESP material in order to bring better results for the course, the material input produced in the CBI approach was then introduced into the TG whereas the CG still learnt with the current ESP one.

\subsubsection{The questionnaire}

The questionnaire was given to all students in two groups. It had two parts covering the following points:

- In the first part of the questionnaire, students were asked about their background as well as their important skills when learning English before joining ESP course.

- The second part of the questionnaire asked students from the TG to express their opinions towards the ESP course designed in the CBI approach.

\subsubsection{The post test}

Following the principle of evaluation, when the quasi-experimental stage finished, the researcher implemented the summative evaluation. This process sought to answer the following questions (Richards, 2001, p. 292):

How effective was the course? Did it achieve its aims?

What did the students learn?

How well was the course received by students and the teacher?

How appropriate were the teaching methods?

"Apart from the relatively informal ways of assessing mastery of objectives, formal tests are probably the commonest means used to measure the achievement" (Richards, 2001, p. 292). Also, Weir (1995, in Richards, 2001, p. 293) points out that "achievement tests can have an important washback effect on teaching and learning".

To this research, the post test was designed by the head of FLF, and it was then given to two groups of students by the researcher at the end of the course. Its details are as follows: 
Part 1: Testing reading comprehension: students were asked to be able to recall vocabulary as well as link their background knowledge of the specialist through matching and multiple choice exercises.

Part 2: Testing language focus: This part aimed at assessing students' writing ability. Translating articles from specialist magazines, or newspapers was of great focus.

Part 3: Testing listening skill: This part tested students the ability to listen to the specialist information so that they could get quick responses in communication.

Besides, oral exercises were also implemented through peer interactions and group presentations in class.

\subsection{Data collection procedures}

The first part of the questionnaire was given to the TG and CG in September 2010. They were asked to answer three questions relating to their English background, their weak skills, and skills useful for their future jobs.

When the quasi-experimental stage finished, it provided with the data coming from two sources: students' questionnaire (the second part) and final test scores. Results in the post test were summarized with the use of Excel application of T-Test to compare two samples for means. The statistics were shown in table 7. Also, data from the questionnaire was also illustrated in table $1,2,3,4,5$, and 6 .

\section{Findings and discussions}

\subsection{Before the quasi-experimental stage}

The aim of this part is to interpret the data (collected from the first part of the questionnaire) about the students' existing English knowledge.

Students from two groups already finished their GE course in the second semester, and they continued their ESP course in the third semester in September 2010.

The survey showed that most students had learned English before they joined GE, and then ESP courses. $62 \%$ of students have learnt English for more than 5 years, 38\% of them have had more than 2 years to equip themselves with necessary English words. These figures also indicate the students' prerequisite English knowledge before they attend English courses at CFC. (See table 1)

In addition to students' GE background, they were also asked to express opinions about their weak skills. This aimed at modifying the current ESP syllabus to meet the students' learning needs. The results showed that the majority of students ( 89 over 100 responses) encountered difficulties when joining listening and speaking skills. This fell on the fact that English was not their major subject, so they just learnt to meet the short-term goal for passing the final exam. (See table 2)

The next question mentioned the students' skills necessary for their future jobs. As being collected from the survey, $70 \%$ of students needed all skills when attending an English language course because these skills all assisted together whenever needed.

On the other hand, $16 \%$ of students showed great concerns towards the reading skill because it was useful for them to read foreign materials supporting them in their study and work. $14 \%$ of students paid much attention about listening and speaking skills. These were very important for them to communicate effectively in work life. (See table 3)

\subsection{After the quasi-experimental stage}

\subsubsection{Data collected from the post test}

As being discussed above, two groups of students were kept separate over a semester. The CG was taught with the current ESP syllabus and traditional method. Whereas the TG was introduced by the selected input organized in the $\mathrm{CBI}$ approach and communicative language teaching.

When the course finished, students of two groups were asked to take the post test. Test content was not extracted right as what two groups learned from the materials. The test was designed to cover all skills from vocabulary matching, reading comprehension, grammar exercise, translation and listening. Students had to combine what they learned through the course of both the language features and specialist contents.

\section{Testing vocabulary}

The first logical step when learning English through the subject matter is to deal with the acquisition of the specialist vocabulary. So, learning vocabulary is thought to be more effective if it is learned from the context. In the CBI approach, students are expected to read texts on specific subject with simplified language and authentic contents. 
It could be seen that almost $84 \%$ of students from the TG got good results on the specialist terminologies. This result was drawn from the learning situation where students had a chance to learn words from contexts and they used them right after the class finished. However, there were still $16 \%$ of students who were assessed to be at the average level. Anyway, this was a minor number in the survey because there was not any student who was weak at this starting step.

Meanwhile, only $24 \%$ of students from the CG were cited to be good at the specialist terminologies. This low figure resulted from the current ESP syllabus which unintentionally forced students to grasp much repetition of vocabulary passively.

\section{Reading comprehension}

With the CBI approach, students can simultaneously use the foreign language to express their thoughts in different situations, and further use it as a tool to comprehend the subject matter in school. To students in the TG, they were exposed to selected authentic materials written in simplified language to explore both content and language skills together.

For the reading skill, before reading the text, students from the TG were asked to make associations among key words, for example, "balance sheet, turnover", and so on. This phase aroused students' learning motivation and interest so that students can have a basic understanding before joining reading texts. This resulted in the high percentage of students $(90 \%)$ to be able to glance the sentence for meanings quickly.

\section{Grammar}

In the CBI approach, students can grasp knowledge of the content and simultaneously cut down the linguistics constituents for language learning. This technique helps kindle students' interest and involvement because they have a chance to access to grammar points interconnected in the specific contexts.

The results showed that students from the TG seemed to be quicker when analyzing the sentence structure and finished anything related to grammar focus. As a result, $70 \%$ of students achieved good marks in grammar exercise, and only $30 \%$ of them were at the average level.

Meanwhile, students from the CG learned so many new words and complex sentence structures from the specialist texts. Therefore, they got deviations and found no central focus when reading. This resulted in the unpleasant scores in the grammar focus. Only $8 \%$ of them attained good marks for this part.

\section{Translation}

When learning ESP, students must be given frequent opportunities to deal with new information and experience in the research for meanings. However, these opportunities should be provided in ways that allow students to do more than just receive information.

In ESP course, translation is also an important skill because it enhances students' writing and speaking at the same time. In reality, accounting jobs require people to be flexible and agile at market information. Therefore, students must be given chances to access to translation of the latest news, or articles in the specialist field.

Because students from the TG were familiar with words of the specialist extracted from magazines, they were not strange when being asked to perform translation tasks. This resulted in the figure of $48 \%$ of students to be at good level, and another $48 \%$ at average level. Only $4 \%$ of them were weak as being compared with $78 \%$ of students from the CG.

\section{Listening}

The present ESP course at CFC tends to focus much on language analysis, so it quietly neglects communicative tasks. To this syllabus, students were transmitted only with words and meanings relating to the field of accounting. With the Grammar Translation Method, students passively received what the teacher delivered only, and there was scant interactive communication in class. This led to the fact that only $14 \%$ of students in the CG were at good level, $34 \%$ average, and $52 \%$ below average.

Meanwhile, students from the TG were exposed to listening financial news, business events, and so on. They became more engaged and facilitated the learning process by combining all skills together. This resulted in $66 \%$ of students were at good level, $26 \%$ at satisfactory and only $8 \%$ of them below average.

In addition to figures helping prove the effectiveness of CBI application, the researcher also used an Excel application to compare two samples for means. Following the principle of doing statistics, the researcher makes a hypothesis before comparing two samples: means difference between two groups was zero $(0)$ - the inefficient interference of CBI approach in the TG. 
However, when the statistics was completed, the indicators in the table helped reject the hypothesis because the absolute value of 11.34607535 is more than $2(/ 11.34607535 />2)$. This statistic showed the negation of the hypothesis - means between two samples was equal. (See table 7)

From the statistics results, the researcher could infer the conclusion that the interference of CBI approach in the TG brought its promising effects for the ESP course.

\subsubsection{Data collected from the questionnaire (second part)}

Students from the TG were asked to join the second part of the questionnaire when they finished the post test. Data collected explored the students' learning style, their opinions towards usefulness of ESP as well as the material input in harmony with the teacher's method in the ESP course incorporated in the CBI approach.

In the CBI approach, all skills taught help employ the students' professional knowledge and prompt them to activate it in a foreign language. The data showed that $84 \%$ of students strongly agreed the usefulness of ESP in learning the specialist. At the same time, they could grasp concepts of the specialist and simultaneously enhanced their language skills. (See table 4)

CBI approach requires students to take part in interactive activities in class. So, the focus of class activities should be to elicit students' knowledge of content, and development of language ability. With data collected in the survey, $10 \%$ of students preferred the traditional learning and teaching. Meanwhile, $15 \%$ of students felt interested in communicative tasks organized by the teacher. These promoted cooperative learning among students and brought positives results in their study. However, $75 \%$ of students were pleased to combine both two methods. For this combination, students had opportunities to employ their specialist knowledge and improve their oral skills. (See table 5)

In addition to the students' learning style, the material input in accordance with the teacher method was of great concern. $92 \%$ of students ( $26 \%$ of students strongly agree and $66 \%$ agree) admitted the benefits they received from the content/ language integration approach. Their motivation was aroused and they felt that they learnt something rather than the language per se. (See table 6)

Also, $\mathrm{CBI}$ is the learner-centred approach, so all materials designed are to meet the learner' needs. Therefore, the teacher acts as a facilitator in the course, and much of work is done by the learners. That was why $92 \%$ of students felt interested and involved in the course. However, $8 \%$ of them seemed not to be familiar with the insecure method in authentic materials due to their exposure in front of class via interactive tasks or group presentations.

\section{Conclusion}

In the view of arousing students' motivation in learning ESP, the researcher conducted the study of incorporating CBI in ESP context with the aim of improving the present ESP syllabus. Results collected from the quasi-experimental stage helped prove the effectiveness of CBI application in the ESP course. This was found through students' motivation during the course as well as their better scores at the end. Therefore, ESP teachers and language developers at CFC should use this study as a source for further research to renovate the current ESP material.

\section{References}

Breen, M. P. (1984). "Process syllabuses for the language classroom" in Brumfit, J. (ed.). General English syllabus design. Pergamon Press Ltd \& The British Council.

Brinton, D. et al. (1989). Content-Based second language instruction. Boston: Heinle \& Heinle Publishers.

Brinton, D. M. \& Master, P. (1997). New ways in Content-Based instruction. Alexandria, VA: TESOL.

Brinton, D. M., Snow \& Wesche, M. (1989). Content-Based second language instruction. New York: Newbury House.

Crandall, J. \& Tucker, C. A. (1990). Content-Based instruction in second and foreign language. Newbury Park, CA: Sage.

Curtain, H. Milwaukee Public Schools and Haas, M. Colombia University. (n.d). Integrating foreign language and content instruction in grades K-8. Retrieved March 16, 2008, from http://w.cal.org/resources/digest/int-for-k8.html

Davies, S. (2003). Content-Based instruction in EFL contexts. Retrieved March 20, 2008, from http://iteslj.org/Articles/Davies-CBI.html 
Duenas, M. (n.d). A description of prototype models for Content-Based language instruction in higher education. Departamento de Filología Inglesa. Universidad de Murcia. Retrieved September 15, 2009, from http://w.publications.ub.es/revistes/bells12/PDF/art04.pdf

Herrero, A., H. (2005). Content-Based Instruction in an English oral communication course at the University of Costa Rica. Universidad de Costa Rica. Retrieved October 15, 2007, from http://revista.inie.ucr.ac.cr/articulos/2-2005/archivos/oral.pdf

Hutchinson, T. \& Waters, A. (1987). English for specific purpose. UK: CUP. doi:10.1017/CBO9780511733031, http://dx.doi.org/10.1017/CBO9780511733031

Kavaliauskiene, G. (2004). Research into the integration of Content-Based instruction into the ESP classroom. Law University of Lithuania, Vilnius, Lithuania. Retrieved March 16, 2008, from http://www.shakespeare.uk.net/journal/jllearn/2_2/kava2_2.html

Kumar, R. (1996). Research methodology (pp. 86-90). Melbourne: Longman.

Met, M. (1999). Content-Based instruction: Defining terms, making decisions. NFLC Reports. Washington, DC. The National Foreign Language Center.

Met, M. (1999). Content-Based instruction: defining terms, making decisions. The National Foreign Language Center. Washington, D.C. Retrieved September 20, from http://carla.umn.edu/cobaltt/modules/principles/decisions.html

Peachey, N. (2003). Content-Based instruction. The British Council. Retrieved September 10, 2007, from http://www.teachingenglish.org.uk/think/article/content-based-instruction

Richards, J. C. \& Rodgers T. S. (1992). Approaches and methods in language teaching. A description and analysis. CUP.

Richards, J. C. \& Rodgers, T. S. (2001). Content-Based instruction. In Approaches and Methods in Language Teaching. CUP. doi:10.1017/CBO9780511667305, http://dx.doi.org/10.1017/CBO9780511667305

Richards, J. C. (2001). Curriculum developing in language teaching. UK: CUP. doi:10.1017/CBO9780511667220, http://dx.doi.org/10.1017/CBO9780511667220

Sticht, T., G. (1997). The theory behind Content-Based instruction. Retrieved September 20, 2007, from http://.ncsall.net/?id=433

Stoller, F., L. \& Grabe, W. (1997). A Six-T's approach to Content-Based instruction. Longman. Retrieved June 25 , 2008, from http://www.carla.umn.edu/cobaltt/modules/curriculum/stoller_grabe1997/6Ts.pdf

Streven, P. (1977). Special-Purpose language teaching: A perspective. Survey article. Language teaching and linguistics abstracts 10(3): 145-163.

Strevens, P. (1980). Teaching English as an international language: From practice to principle. Oxford: Pergamon Press

Strevens, P. (1988). The learner and teacher of ESP. Modern English Publications in association with the British Council.

Stryker, S. \& Leaver, B. L. (1997). Content-Based instruction in foreign language education: Models and methods. Washington, DC: Georgetown University Press.

The practice of learning theories/ CBI: Content-Based instruction in language learning. (n.d.). Retreived August 20, 2007, from http://en.wikibooks.org/wiki/The_Practice_of_Learning_Theories/CBI 
Table 1.

\begin{tabular}{|l|l|}
\hline \multicolumn{2}{|c|}{ English study background } \\
\hline Years of learning English & Percent \\
\hline More than 5 & $62 \%$ \\
\hline From 2 to 5 & $23 \%$ \\
\hline Less than 2 & $15 \%$ \\
\hline
\end{tabular}

Table 2.

\begin{tabular}{|l|l|}
\hline \multicolumn{2}{|c|}{ Students' skills weakness } \\
\hline Skills & Percent \\
\hline Listening \& Speaking & $89 \%$ \\
\hline Reading & $5 \%$ \\
\hline Translation & $6 \%$ \\
\hline
\end{tabular}

Table 3.

\begin{tabular}{|l|l|}
\hline \multicolumn{2}{|l|}{ Skills important for future job } \\
\hline Skills & Percent \\
\hline All skills & $70 \%$ \\
\hline Reading & $16 \%$ \\
\hline Listening \& Speaking & $14 \%$ \\
\hline
\end{tabular}

Table 4.

\begin{tabular}{|l|l|}
\hline \multicolumn{2}{|c|}{ The usefulness of ESP } \\
\hline & Percent \\
\hline Strongly agree & $84 \%$ \\
\hline Agree & $16 \%$ \\
\hline No opinion & $0 \%$ \\
\hline Disagree & $0 \%$ \\
\hline
\end{tabular}


Table 5 .

\begin{tabular}{|l|l|}
\hline \multicolumn{2}{|c|}{ Students' ESP learning style } \\
\hline & Percent \\
\hline Passive learning style & $10 \%$ \\
\hline Active learning style & $15 \%$ \\
\hline Active \& Passive combination & $75 \%$ \\
\hline
\end{tabular}

Table 6.

\begin{tabular}{|l|l|}
\hline Material input in the CBI approach \\
\hline & Percent \\
\hline Strongly agree & $26 \%$ \\
\hline Agree & $66 \%$ \\
\hline No opinion & $0 \%$ \\
\hline Disagree & $8 \%$ \\
\hline
\end{tabular}

Table 7.

\begin{tabular}{|l|l|l|}
\hline \multicolumn{3}{|c|}{ t-Test: Paired Two Sample for Means } \\
\hline & Variable 1 & Variable 2 \\
\hline Means & 7.88 & 6.14 \\
\hline Variance & 0.475102041 & 0.653469388 \\
\hline Observations & 50 & 50 \\
\hline t Stat & 11.34607535 & \\
\hline
\end{tabular}




\section{APPENDIX}

\section{QUESTIONNAIRE}

\section{(For students of Accounting Major)}

This questionnaire aims at colleting data from students in favor of designing a comprehensible ESP syllabus appropriate to the students' needs.

Please answer either by ticking $\checkmark$ the appropriate box, circling the number or writing in the spaces provided.

\section{Part 1: Before the quasi-experimental period}

1. How long have you learned English?

- Less than 1 year

- From 1 to less than 3 years [ ]

- From 3 to less than 5 years [ ]

- More than 5 years [ ]

2. When learning English, which skills are your weakest?

$\begin{array}{lrlllll}\text { Listening \& Speaking } & {[} & ] & \text { Reading } & {[} & \text { ] } \\ \text { Writing } & {[} & ] & \text { Translating [ }\end{array}$

3. In you opinion, what skills are important to your future job?

Listening \& Speaking

Writing

$\left.\begin{array}{lll}\text { Reading } & {[} & ] \\ \text { Translating } & {[} & {[}\end{array}\right]$

All of the above

\section{Part 2: After the quasi-experimental period}

Please circle the choice that is closest to your personal belief.

\begin{tabular}{|l|l|l|l|}
\hline Strongly agree & Agree & No opinion & Disagree \\
1 & 2 & 3 & 4 \\
\hline
\end{tabular}

4. In your view, ESP is useful for your future job. $\begin{array}{lllll}1 & 2 & 3 & 4\end{array}$

5. When joining ESP course, which of the following styles do you prefer to learn?

- Listening to ESP teacher and taking notes (passive learning) [ ]

- Taking part in communicative activities (communicative learning) [ ]

- Combination of the two

- Your own ideas:

6. According to you, the material input designed in the CBI approach is authentic, relevant and comprehensible.

$\begin{array}{llll}1 & 2 & 3 & 4\end{array}$

\section{Thank you for your cooperation!}

